\author{
AGNIESZKA KAWALEC \\ https://orcid.org/0000-0002-3144-318 \\ Uniwersytet Rzeszowski
}

\title{
U POCZĄTKÓW MODERNIZACJI STUDIUM HISTORYCZNEGO NA UNIWERSYTECIE JAGIELLOŃSKIM. STARANIA KSAWEREGO LISKEGO I WINCENTEGO ZAKRZEWSKIEGO O KATEDRĘ HISTORII POWSZECHNEJ NA UJ
}

\begin{abstract}
Abstrakt: Tekst poświęcony jest dziejom Katedry Historii Powszechnej Uniwersytetu Jagiellońskiego w końcowym okresie polonizacji Wydziału Filozoficznego UJ. Przedstawia burzliwy czas wymiany kadrowej, przypadającej na lata 1869-1872, a w szczególności starania Ksawerego Liskego i Wincentego Zakrzewskiego o profesurę UJ, wspierane przez niedawno powołanego profesora historii polskiej Józefa Szujskiego. Wymienieni historycy zapoczątkowali proces profesjonalizacji badań historycznych w Krakowie i Lwowie, współtworzyli zaplecze instytucjonalne, zaprowadzili nowe standardy kształcenia, przenosząc na grunt polski wzorce niemieckiej szkoły krytycznej.
\end{abstract}

Słowa kluczowe: Ksawery Liske, Wincenty Zakrzewski, Józef Szujski, Uniwersytet Jagielloński, Katedra Historii Powszechnej, modernizacja studium historycznego UJ.
Abstract: The text is devoted to the history of the Department of General History at the Jagiellonian University in the final period of Polonization of the Faculty of Philosophy. It presents the turbulent time of the personnel exchange in 1869-72, and especially the efforts of Ksawery Liske and Wincenty Zakrzewski for a professorship at the University, supported by the recently appointed professor of Polish history, Józef Szujski. These historians initiated the process of professionalization of historical research in Cracow and Lwów (Lviv, Lemberg), jointly established the institutional back-up facilities, and introduced new educational standards by transferring the models of the German critical school to Poland.

Keywords: Ksawery Liske, Wincenty Zakrzewski, Józef Szujski, Jagiellonian University, Department of General History, modernization of historical study at the Jagiellonian University. 
Nieco ponad 150 lat temu na Wydziale Filozoficznym Uniwersytetu Jagiellońskiego utworzona została pierwsza Katedra Historii Polskiej, z polskim językiem wykładowym. Po wielomiesięcznych staraniach objął ją Józef Szujski, mianowany przez cesarza we wrześniu 1869 r. na profesora zwyczajnego ${ }^{1}$. Zarówno powołanie katedry, jak i nominacja historyka młodego pokolenia wpisywały się w proces polonizacji Uniwersytetu Jagiellońskiego, który wszedł w ostatnią fazę, zakończoną w Krakowie w roku akademickim $1870 / 1871^{2}$, ale też zapoczątkowały profesjonalizację badań historycznych oraz modernizację studium historycznego $\mathrm{UJ}^{3}$. Proces ten był długotrwały i wymagał wielu wysiłków, ale wydaje się, że był realizowany w sposób przemyślany i konsekwentny. Szujski, jeden z czołowych inicjatorów zmian w Krakowie, wykorzystując sytuację polityczną oraz ożywione nastroje społeczne towarzyszące repolonizacji uniwersytetu, próbował pozyskać dla studium historycznego UJ badaczy, którzy realizowaliby najwyższe standardy w nauce historycznej.

Główny akcent w niniejszym opracowaniu położono na mało znane zagadnienie związane z nieudaną próbą pozbawienia prof. Antoniego Wachholza funkcji kierownika Katedry Historii Powszechnej i Austriackiej w 1869 r., a następnie obsadzenia drugiej Katedry Historii Powszechnej (sfinalizowanego dopiero latem 1872 r.), po przejściu w stan spoczynku prof. Antoniego Walewskiego. Problem będzie rozpatrywany szczególnie w kontekście starań o tę katedrę Ksawerego Liskego i Wincentego Zakrzewskiego, dwóch świetnie zapowiadających się historyków, którzy niebawem zdobędą pozycję czołowych przedstawicieli historiografii polskiej w Galicji. Jednocześnie podkreślono rolę Szujskiego w tych zabiegach, jak się okazuje kluczową i decydującą.

Przy okazji tych zawiłych działań obserwujemy, w jaki sposób Szujski, Liske i Zakrzewski budowali pozycję naukową na początku kariery akademickiej, poznajemy krąg przychylnych im osób, metody pracy, determinację w dążeniu do celu, ale też umiejętność poruszania się wśród osób reprezentujących różne opcje polityczne.

${ }^{1}$ Nominację tę ogłoszono na Radzie Wydziału 9 listopada 1869 r., Archiwum Uniwersytetu Jagiellońskiego, Wydział Filozoficzny (dalej: AUJ, WF) II 42, Protokoły posiedzeń Rady Wydziału Filozoficznego z lat 1865/66-1874, Protokół z 9 XI 1869 r., k. 154.

${ }^{2}$ Kronika Uniwersytetu Jagiellońskiego od r. 1864 do r. 1887 i obraz jego stanu dzisiejszego wraz z rzeczą o rektorach od czasów najdawniejszych (dalej: Kronika UJ), Kraków 1887, s. 5-6, 17. Szeroko na ten temat: M. Stinia, Katedra historii polskiej na Uniwersytecie Jagiellońskim, w: Katedra historii polskiej na Uniwersytecie Jagiellońskim - odniesienia, interpretacje, pamięć, red. K.K. Daszyk, T. Kargol, Kraków 2019, s. 9-13.

${ }^{3}$ J. Maternicki, Historia i życie narodu. Poglady i postawy historyków polskich XIX i XX w., Rzeszów 2009, s. 134-136. 
Szansa do zmiany kierownictwa Katedry Historii Powszechnej i Austriackiej UJ pojawiła się tuż po nominacji Szujskiego na profesora zwyczajnego uniwersytetu. Kierownik Katedry Historii Polskiej od razu starał się wykorzystać tę okazję. Na październikowym posiedzeniu Rady Wydziału Filozoficznego w 1869 r. przedstawiono odezwę Senatu UJ, będącą efektem ponaglenia ze strony namiestnika Galicji, Ludwika Possingera-Choborskiego, z października tego roku „w przedmiocie zaprowadzenia polskich wykładów na wszystkich katedrach tamtejszej wszechnicy i przedstawienia w tym celu kandydatów jak najspieszniej"4. Na Wydziale Filozoficznym UJ w tym czasie istniały trzy katedry z wykładowym językiem niemieckim: Katedra Języka i Literatury Niemieckiej, obsadzona przez prof. Franciszka Tomasza Bratranka, jedna z Katedr Filologii Klasycznej pod kierunkiem prof. Jana Wróbla oraz jedna z dwu Katedr Historii Powszechnej i Austriackiej ${ }^{5}$, kierowana przez prof. Antoniego Wachholza ${ }^{6}$. Obaj filolodzy potwierdzili, że nie są w stanie wykładać po polsku, natomiast historyk, pomimo deklaracji o gotowości do wykładów w języku polskim, nie zdobył akceptacji członków Rady Wydziału Filozoficznego. W tej sytuacji powołana została komisja, której celem miał być wybór najlepszych kandydatów na trzy katedry. W jej skład weszli: dziekan - prof. Franciszek Karliński (astronom, matematyk) oraz profesorowie: Antoni Walewski (historyk), Alfred Brandowski (filolog klasyczny), Józef Kremer (filozof) oraz, na wniosek Walewskiego, prezes ck komisji egzaminacyjnej dla kandydatów na nauczycieli gimnazjalnych Napoleon Czerwiakowski (botanik, lekarz) ${ }^{7}$.

${ }^{4}$ AUJ, WF II 62, Wprowadzenie języka polskiego jako wykładowego w Wydziale Filozoficznym 1861-1862, 1869, Prezydium Namiestnictwa we Lwowie do Senatu UJ, odpis pisma z 11 X 1869 r., b.pag.

${ }^{5}$ Drugą katedrą kierował od 1851 r. Antoni Walewski, który wśród Polaków cieszył się złą sławą. W 1853 r. dobrowolnie wnioskował, aby językiem wykładów na UJ był język niemiecki. Antoni Małecki, profesor języka i literatury polskiej na Uniwersytecie Lwowskim, pisał o nim: „Łotrzysko! Głupi i zły, prawdziwa to hańba dla Uniwersytetu”. W wyniku zmieniającej się sytuacji politycznej w $1860 \mathrm{r}$. Walewski zmuszony został do podjęcia wykładów w języku polskim, wówczas to, dla zachowania równowagi, rząd ustanowił drugą Katedrę Historii Powszechnej i Austriackiej z językiem wykładowym niemieckim, na którą powołano ze Lwowa prof. Antoniego Wachholza. Obydwaj nastawieni byli proaustriacko, H. Barycz, Krakowskie przygody Wojciecha Kętrzyńskiego, w: Wśród gawędziarzy pamiętnikarzy $i$ uczonych galicyjskich. Studia i sylwety z życia umysłowego Galicji w XIX w., t. 2, Kraków 1963, s. 92-93. W Kronice UJ z 1887 r. znajdujemy m.in. zapis: „człowiek niezaprzeczalnie zdolny i pracowity, umysł oryginalny i głębszy, ale przy tym całkiem spaczony, doktryner szczególnego rodzaju, popadający w końcu w czysto chorobliwe majaczenia w Filozofii dziejów Polski", Kronika UJ, s. 19-20.

${ }^{6}$ AUJ, WF II 42, Protokół z 8 X 1869 r., k. 147-148.

7 Ibidem. 
Ze względu na presję czasu komisja samodzielnie na posiedzeniu 14 października zaproponowała senatowi UJ dwóch kandydatów do objęcia Katedry Historii Powszechnej i Austriackiej: dra Wojciecha Kętrzyńskiego, mediewistę, bibliotekarza kolekcji Jana Działyńskiego w Kórniku, zaangażowanego w wydanie dziewiątego tomu Aktów Tomicianów, który niespełna rok wcześniej rywalizował, bez powodzenia, z Józefem Szujskim o Katedrę Historii Polskiej, oraz dra Ksawerego Liskego, nowożytnika, od kwietnia 1869 r. docenta na Uniwersytecie Lwowskim. Obaj - równolatkowie urodzeni w 1838 r. - byli absolwentami niemieckich uniwersytetów, obaj studiowali u najwybitniejszych wówczas autorytetów w dziedzinie historii ${ }^{8}$ i posiadali wartościowy dorobek naukowy. Komisja od razu powiadomiła ich o konkursie, kierując prośbę o przedstawienie niezbędnych dokumentów (podania, życiorysu, dorobku naukowego) ${ }^{9}$. Wydawało się, że faworytem w tym starciu jest Kętrzyński, który dał się już poznać krakowskim historykom, miał poparcie dwóch członków komisji: był „gorąco nader polecany przez” profesorów Walewskiego i Brandowskiego, miał również przychylność prof. Józefa Majera i ówczesnego rektora UJ Fryderyka Skobla ${ }^{10}$. Natomiast, jak pisano: „Mniej jest znany komisji Pan Ksawery Liske, który się nie udziela tak, jak Pan Kętrzyński uczonym krakowskim. Jak jednakowoż powszechnie

${ }^{8}$ Kętrzyński studiował w Królewcu, m.in. u Friedricha Wilhelma von Giesebrechta (wychowanek szkoły historycznej Leopolda Rankego), uczęszczał na seminaria Friedricha Wilhelma Schuberta, wykłady Karla Wilhelma Nitscha (historia starożytna), Johanna Voita (nauki pomocnicze historii), Juliusza Zachera (znawca języka starogermańskiego - pomogło to Kętrzyńskiemu w odczytywaniu dokumentów krzyżackich). Liske we Wrocławiu studiował m.in. u Richarda Roepella, Wilhelma Junkmanna, Colmara Grünhagena (dyplomatyka), Gustawa Stenzla (filologia klasyczna) czy Wojciecha Cybulskiego (literatura polska i niemiecka), w Berlinie u Leopolda Rankego, Johanna Gustava Droysena (największe autorytety w dziedzinie historii tego czasu, u obu uczestniczył głównie w ćwiczeniach i seminariach), Philippa Jaffé (paleografia i dyplomatyka); doktorat obronił w Lipsku u Georga Voigta. Podczas pobytu w Niemczech wyrobił sobie ważne kontakty naukowe w tamtejszym środowisku, publikował swe prace w „Forschungen zur Deutschen” u Georga Waitza oraz w „Historische Zeitschrift” u Heinricha Sybla, K. Korzon, Wojciech Kętrzyński 1838-1918. Zarys biograficzny, Wrocław 1993, s. 46-54; S. Achremczyk, Wojciech Kętrzyński, historyk, bibliotekarz, poeta, Kętrzyn 2008, s. 28-34; W. Zakrzewski, Xawery Liske, 1838-1891. Wspomnienie pośmiertne, Kraków 1891, s. 9-13; O. Balzer, W. Zakrzewski, L. Finkel, L. Ćwikliński, J.H. Sawczyński, Z. Hordyński, Xawery Liske. Zarys biograficzny, KH 5, 1891, s. 468-476; V. Julkowska, Ksawery Liske (1838-1891), w: Złota księga historiografii lwowskiej, red. J. Maternicki, L. Zaszkilniak, Rzeszów 2007, s. 184-186; K. Zamorski, Historyzm i narodziny krakowskiej szkoły historycznej. Józef Szujski, w: Józef Szujski 1835-1883. Materiały z posiedzenia naukowego w dniu 25 listopada 2013 roku, red. W. Lohman, Kraków 2015, s. 56-59.

9 AUJ, WF II 42, Protokół z 8 X 1869 r., k. 147-148.

10 AUJ, WF 62, Sprawozdanie komisji z 12 X 1869, k. 5; H. Barycz, op. cit., s. 125. 
wiadomo, oddaje się Pan Liske, docent przy Uniwersytecie Lwowskim, cenionym przez znawców poszukiwaniom archiwalnym, które mu zjednały pomiędzy literatami naszymi imię pilnego badacza"11. Kandydatura Liskego została wzięta pod uwagę przez komisję z inspiracji Szujskiego, który znał i recenzował jego dorobek naukowy już w $1867 \mathrm{r}^{12}$

Ksawery Liske jeszcze podczas pobytu w Berlinie w 1867 r. szukał sposobu, by znaleźć posadę w Galicji - najlepiej w Krakowie lub we Lwowie, na uniwersytecie lub choćby w czasopiśmie naukowym. W tym celu prosił o protekcję Józefa Ignacego Kraszewskiego, który rozmawiał w jego sprawie z uczonymi krakowskimi, m.in. z redaktorami „Przeglądu Polskiego" (m.in. Szujskim) ${ }^{13}$. Rozmowy te zakończyły się niepowodzeniem w Krakowie, ale wkrótce pojawiła się szansa na zatrudnienie we Lwowie, głównie dzięki wsparciu prof. Antoniego Małeckiego i Augusta Bielowskiego. Od 1 stycznia 1869 r. Liske kierował już wydawnictwem akt grodzkich i ziemskich w Archiwum Bernardyńskim, w marcu tr. przeprowadził nostryfikację dyplomu doktorskiego na Uniwersytecie Lwowskim, w kwietniu uzyskał habilitację i posadę docenta. W tym czasie miał oparcie także w Heinrichu Zeissbergu, profesorze historii powszechnej na tejże uczelni ${ }^{14}$.

W Krakowie Liske znany był głównie z publikacji: m.in. Studiów z dziejów XVI w. oraz z wydanej anonimowo w „Historische Zeitschrift” pracy: Übersicht der polnischen historischen Literatur der letzten Jahre (Przegląd polskiej literatury historycznej ostatnich lat) ${ }^{15}$, krytycznej wobec polskiej

11 AUJ, WF II 42, Protokół z 8 X 1869 r., k. 147-148; AUJ, WF II 62, Sprawozdanie komisji z 12 X 1869, k. 5.

${ }^{12}$ J. Szujski, Studia z dziejów wieku XVI, napisał Xawery Liske, dr fil.[ozofii], Poznań, nakładem księgarni Żupańskiego, „Przegląd Polski” 2, 1867, 1, 3, s. 465-467; w „Kronice bibliograficznej" krótka recenzja tekstu: idem, Przegląd historycznej literatury polskiej lat ostatnich, „Przegląd Polski” 2, 1868, 3, 9, s. 508 [oryg. Übersicht der polnischen historischen Literatur der letzten Jahre, „Historische Zeitschrift” 1867].

13 List K. Liskego do J.I. Kraszewskiego, Berlin 15 IV 1867 oraz list J.I. Kraszewskiego do K. Liskego, Drezno 23 IV 1867, w: A. Kawalec, Z Wielkopolski do Lwowa - w pogoni za realizacja marzeń . Przypadek Ksawerego Liskego w świetle korespondencji, „Galicja. Studia i Materiały" 5, 2019, s. 333-335; A.F. Grabski, Polityka i Katedra Historii Polskiej, w: idem, Troski i nadzieje. Z dziejów polskiej myśli społecznej i politycznej XIX w., Łódź 1981, s. 292. „Przegląd Polski” - miesięcznik poświęcony nauce i literaturze, wydawany w latach 1866-1914 przez konserwatystów krakowskich: Stanisława Koźmiana, Józefa Szujskiego, Stanisława Tarnowskiego, Ludwika Wodzickiego; w 1869 r. na jego łamach opublikowano Tekę Stańczyka.

${ }^{14}$ Szerzej: A. Kawalec, Z Wielkopolski do Lwowa, s. 311-351.

15 [K. Liske], Übersicht der polnischen historischen Literatur der letzten Jahre, „Historische Zeitschrift" 18, 1867, s. 359-410; https://www.digizeitschriften.de/download/ PPN331411849_1867_0018/PPN331411849_1867_0018__log16.pdf (dostęp: 3 I 2020). 
historiografii. Wydaje się, że domyślano się autorstwa. Młody badacz poważył się na surową ocenę znanych historyków polskich, przez co przysporzył sobie wielu wrogów, m.in. w środowisku krakowskim. Przyświecał mu wprawdzie szlachetny cel. Sam profesjonalnie przygotowany do pracy badawczej, chciał przeszczepić metodę analizy krytycznej na grunt polskiej nauki historycznej. Choć zarzuty niedostatecznych umiejętności warsztatowych stawiane przez Liskego ówczesnym historykom były słuszne to, jak zauważa Violetta Julkowska, były „zupełnie nieadekwatne do warunków, w jakich oni tworzyli". Artykuł ten ujawnił ogromną dysproporcję pomiędzy fachowym przygotowaniem Liskego, a poziomem prac historycznych pisanych przez historyków amatorów ${ }^{16}$. Rozumiał to Szujski, który poczuł się w obowiązku do reakcji na tę jego zdaniem - w wielu wypadkach krzywdzącą ocenę: „Właśnie dlatego, że pomieniony artykuł bardzo pochlebnie wyraża się o naszym piśmie [„Przegląd Polski” - A.K.] - pisał w swej recenzji - możemy zaprotestować przeciwko niejednej rzeczy w nim zawartej, bez obawy, aby nas o osobistość posądzić miano. Amicus Plato... Na miękkość i krzykliwość krytyki naszej zgoda... ale niezgoda na zdanie o kilku autorach i usiłowaniach historycznych w ogólności"17.

Wydaje się, że relacje obu historyków w tym czasie były dość chłodne. Z czasem jednak wspólne zainteresowania naukowe zbliżyły ich do siebie i Szujski został cichym sprzymierzeńcem Liskego w staraniach o katedrę. To on wskazał komisji wydziałowej jego nazwisko jako potencjalnego kandydata, to on informował Liskego listownie o przebiegu konkursu, doradzał mu strategię w staraniach o stanowisko.

Po zapoznaniu się z przesłanymi przez kandydatów dokumentami, komisja konkursowa zaproponowała Kętrzyńskiego na zwyczajnego profesora historii powszechnej i austriackiej z językiem wykładowym polskim, prezentując bardzo obszerne uzasadnienie, podkreślające pozytywną ocenę jego dorobku. Natomiast kandydatura Liskego została kategorycznie odrzucona, z pominięciem nawet oceny jego dokonań naukowych. W sprawozdaniu komisji z 22 października 1869 r. czytamy:

Do katedry historii powszechnej i austriackiej zgłosił się oprócz pana Kętrzyńskiego jeszcze lwowski docent prywatny pan Liske i położył warunek, aby go Prześwietne Grono na profesora zwyczajnego zaproponowało. Co się tego kandydata dotyczy, to komisja w żaden sposób Prześwietnemu

${ }^{16}$ Szerzej pisze o tym V. Julkowska, Historia dla wyobraźni. Recepcja i interpretacja pisarstwa historycznego Karola Szajnochy, Poznań 2010, s. 127-134.

17 Por. przyp. 12. 
Gronu polecić nie może. Nie wchodząc bowiem w rozbiór naukowy wartości jego publikacji, uważa sobie komisja za obowiązek zwróć uwagę Prześwietnego Grona na jego postępowanie nie znamionujące bynajmniej człowieka dbałego o zwykłą nawet przyzwoitość. Ubiegając się o rzeczoną katedrę z takim uroszczeniem [pretensją, roszczeniem - A.K.] przesłał pan Liske Prześwietnemu Gronu niby na urągowisko szpetny pamflet, niegdyś bezimiennie ogłoszony, do którego teraz z chlubą się przyznaje, a tym samym śmiał on sam sobie wystawić świadectwo zupełnego barku taktu i poczucia godności przyszłego profesora uniwersyteckiego [wyróżnienie - A.K.].

Pod dokumentem podpisali się: Alfred Brandowski jako sprawozdawca komisji oraz członkowie: Antoni Walewski, Józef Kremer i dziekan Franciszek Karliński ${ }^{18}$.

Jak należy się domyślać, Liske przesłał do oceny, obok prac historycznych, również wspomniany przegląd polskiej literatury historycznej, tekst, który tak bardzo zbulwersował członków komisji. Spory fragment tej pracy poświęcony był twórczości prof. Walewskiego - jedynego historyka w tym gronie.

Liske był pierwszym recenzentem, który tak bezceremonialnie ocenił pisarstwo Walewskiego na łamach prestiżowego niemieckiego pisma naukowego. Wziął na warsztat świeżo wydany pierwszy tom Historii wyzwolenia Polski za panowania Jana Kazimierza 1655-166019, wspomniał także, że autor znany jest niemieckim czytelnikom z historii Świętej Ligi i cesarza Leopolda ${ }^{20}$, o której pisał: „nazywam to dzieło głośnym, bo chyba nie ma innej książki, która zawierałaby tak szalone pomysły, jak ta właśnie wspomniana”. Liske tak charakteryzował autora prac: „Walewski jest bardziej austriacki niż cesarz Austrii, bardziej katolicki niż sam papież. Jego konserwatyzm, jego stronniczość, jego tendencyjne dążenia przekraczają wszelkie granice. Pozostał wierny tej postawie w dziełach napisanych w języku polskim; wydaje się, że to jedyny powód, dla którego wybrał ten temat, by pokazać, jak zawsze polityka Austrii była szlachetna wobec Polski, jak bardzo przyczyniła się do uratowania kraju". Analizując stronę faktograficzną monografii o Janie Kazimierzu, nie szczędził słów krytyki, docenił jednak wysiłek autora polegający na wykorzystaniu

18 AUJ, WF II 62, Sprawozdanie komisji z 22 X 1869 r., k. 5.

19 A. Walewski, Historia wyzwolenia Polski za panowania Jana Kazimierza 1655-1660, t. 1, Kraków 1866, t. 2, Kraków 1868.

${ }^{20}$ A. Walewski, Geschichte der hl. Ligue und Leopolds I. vom Umschwung im Gleichgewichtssystem des Westens durch den schwedisch - polnisch - österreichischen Krieg, bis zur Verwicklung der orientalischen Frage durch August II 1657-1700, t. 1, cz. 1, Kraków 1857. 
materiału źródłowego znajdującego się w zasobach archiwów wiedeńskich, zwracał uwagę na umiejętne przedstawienie stosunków dyplomatycznych polsko-austriackich, ale całość kwitował smutną konstatacją:

Dzięki bogatemu materiałowi z wiedeńskiego archiwum był w stanie przedstawić wiele rzeczy, które wcześniej były całkowicie nieznane. Ale jest tak stronniczy w swojej narracji, że musimy być ostrożni, nawet tam, gdzie przedstawia dokumenty archiwalne jako dowód [wyróżnienie - A.K.]. Ktokolwiek kieruje się tak tendencyjnymi postawami w ocenie ludzi i okoliczności, kto może wymyślić tak zawiłe pomysły, nigdy nie będzie w stanie wzbudzić w nas pełnego zaufania do korzystania z materiałów archiwalnych. Specyfika jego punktu widzenia jest również widoczna w opiniach, które wypowiedział wobec polskich królów Władysława IV i Jana Kazimierza. Historycznie ustalono [--], że rząd króla Władysława wyróżnia się wieloma dobrymi i korzystnymi rzeczami dla państwa (czytaj w mistrzowskim dziele [Karola] Szajnochy: Dwa lata dziejów naszych) [--], a jednak Pan Walewski zawsze lubi nazywać rząd tego monarchy głupotą, podczas gdy dla niego Jan Kazimierz, któremu brakowało wszelkiego ducha politycznego i talentu, był mężem stanu, generałem i żołnierzem wielkiej miary. Taki pogląd jest wystarczający do scharakteryzowania stanowiska autora $^{21}$.

Zastanawiające jest, że rok wcześniej Józef Szujski, w swej odpowiedzi na recenzję Liskego, stanął w obronie książki Walewskiego. Pisał wówczas: „Książka pana Walewskiego zasługuje na wysokie uznanie, choćby dlatego, że nam daje o dyplomatycznych stosunkach Austrii i Polski to, czego nikt inny dać nie mógł, a niestrojność myśli autora do faktów przytoczonych, jest właśnie najlepszym dowodem, że podał sumiennie co wiedział. Możemy mu zatem przebaczyć jego przekonania, choćby utopiami być miały"22. Być może była to obrona koniunkturalna, w tym czasie bowiem toczyła się sprawa objęcia katedry na UJ przez Szujskiego, a decydujący głos miał mieć prof. Walewski.

Nie dziwi zatem fakt, że Walewski utrącił kandydaturę Liskego. Nurtuje jednak pytanie, dlaczego Liske załączył ten tekst do dokumentacji konkursowej, skoro wiedział, że Walewski ma decydujący głos w komisji. Przecież zależało mu na tej posadzie. Czy był aż tak pewny siebie?

Znając charakter Liskego, a w sprawach nauki był bezkompromisowym i wymagającym badaczem, można przypuszczać, że chciał zdobyć tę katedrę przebojem. Z pewnością znał złą sławę prof. Walewskiego, jego

${ }^{21}$ [K. Liske], Übersicht der polnischen historischen Literatur, s. 379-381.

22 J. Szujski, Przeglad historycznej literatury polskiej, s. 508. 
ponurą historię błyskawicznej kariery naukowej na Uniwersytecie Jagiellońskim chociażby z relacji prof. Małeckiego, który w 1853 r. wraz z Wincentym Polem, Jozefatem Zielonackim i Zygmuntem Antonim Helzlem stracił posadę na UJ za sprawą denuncjacji i intryg Walewskiego ${ }^{23}$. Wiedział, że nazwiska profesorów Józefa Kremera i Juliana Dunajewskiego widniały $\mathrm{w}$ jego donosach i ich los na uczelni był niepewny. Teraz, po prawie dwudziestu latach, osoby te współdecydowały o wyborze kandydata na stanowisko profesora katedry, a czas niesławnego historyka w murach uniwersyteckich powoli dobiegał już końca. Wiedział również, że ma cichego sojusznika w osobie Józefa Szujskiego, który również miał kłopoty za sprawą Walewskiego, gdy ten utrudniał mu zdobycie Katedry Historii Polskiej na UJ. Liske mógł mieć nadzieję, że w obliczu zmieniającej się sytuacji politycznej w Galicji ma szansę na katedrę, a publiczne upokorzenie Walewskiego przysporzy mu sympatyków.

Niestety przeliczył się. Decyzją o załączeniu tekstu do dokumentów zamknął sobie drogę do Katedry Historii Powszechnej i Austriackiej na UJ. Sprawa obiła się głośnym echem, relacjonował ją również Kętrzyński swemu chlebodawcy, Janowi Działyńskiemu, pisząc, że „Liske Ksawery wskutek nieroztropnego i beztaktownego wystąpienia spadł z listy kandydatów" ${ }^{24}$.

Jak się wkrótce okazało, mimo pozytywnej oceny także Kętrzyński katedry nie otrzymał. Wprawdzie Wydział Filozoficzny przesłał do namiestnictwa pozytywną rekomendację jego kandydatury, ale wobec informacji kompromitujących historyka w oczach władzy (udział w powstaniu styczniowym i kara więzienia, o których sam wspomniał w curriculum vitae), namiestnik galicyjski Possinger-Choborski uznał za konieczne zasięgnięcię opinii w jego sprawie w Berlinie (Kętrzyński był pruskim poddanym, obywatelstwo austriackie otrzymał dopiero 4 marca 1880 r.). Oficjalna korespondencja w tej sprawie krążyła od listopada do końca grudnia 1869 r. pomiędzy pruskim ministrem spraw zagranicznych, ministrem spraw wewnętrznych i nadprezydentem prowincji poznańskiej ${ }^{25}$. Kętrzyński zdawał sobie sprawę z działań władz austriackich i pruskich, gdyż już w grudniu 1869 r. otrzymał niepokojącą informację z Berlina od przebywającego tam Jana Działyńskiego: „Pan Jan

${ }^{23}$ Szerzej o Walewskim: K. Baczkowski, W stużbie dworu habsburskiego. Antoni Walewski (1805-1876), „Zeszyty Naukowe Uniwersytetu Jagiellońskiego” 1279, „Prace Historyczne" 2005, 132, s. 99-102.

${ }^{24}$ Cyt. za: W. Chojnacki, Wojciech Kętrzyński a Mazury, „Rocznik Zakładu Narodowego imienia Ossolińskich" 3, 1948, s. 30 [558].

${ }^{25}$ A. Skrobacki, Dlaczego Wojciech Kętrzyński nie otrzymał katedry na Uniwersytecie Krakowskim w 1869 roku?, „Komunikaty Warmińsko-Mazurskie” 1973, 3, s. 209-211. 
powiadał mi - pisał Zygmunt Celichowski - że rząd austriacki zapytywał się tutejszego rządu o Pana przeszłość. Mam otuchę, że mimowolny Pański pobyt w Hausvogtei i w Kłodzku nie wpłynie na decyzję szanownych krakowian. Czyś Pan już potwierdzenie rządowe otrzymał?"26.

Równocześnie z korespondencją dyplomatyczną skierowaną do rządu pruskiego, z namiestnictwa galicyjskiego wysłano listy do Ministerstwa Wyznań i Oświecenia w Wiedniu z sugestią, by do czasu wyjaśnienia sprawy tymczasowo powierzyć Katedrę Historii Powszechnej i Austriackiej prof. Antoniemu Wachholzowi (pozostały mu zaledwie trzy lata do emerytury, miał wykładać po polsku). Uprzedzano jednocześnie, że gdyby z jakichkolwiek powodów wypadła kandydatura Kętrzyńskiego, namiestnik będzie proponował nominację Liskego na profesora nadzwyczajnego. Ewidentnie Possinger-Choborski skłaniał się ku jego kandydaturze ${ }^{27}$.

Podobne stanowisko zajął prof. Julian Dunajewski, prorektor UJ. W piśmie towarzyszącym sprawozdaniu dziekana z 25 października 1869 r., zastrzegając się, że nie chce wchodzić w merytoryczną ocenę wydziału, wypowiedział się jednakże za utrzymaniem wniosku o powołanie Liskego na profesora zwyczajnego. Stanowisko Dunajewskiego wywołało burzę, nawet prof. Brandowski udał się do niego z interwencją w tej sprawie, ale bezskutecznie. Rektor stwierdził, że nie protestował przeciwko Kętrzyńskiemu, ale zmodyfikował opinię wydziału o historyku ze Lwowa. Henryk Barycz sugerował, że Dunajewski podjął tę decyzję pod wpływem Szujskiego, który nie uczestniczył w październikowym posiedzeniu Rady Wydziału ${ }^{28}$. Wkrótce Possinger-Choborski otrzymał z Berlina potwierdzenie udziału Kętrzyńskiego w powstaniu i oskarżenia go o zdradę stanu, a także kary więzienia. To z kolei dyskwalifikowało Kętrzyńskiego z dalszej walki o katedrę. Pamiętamy jednak, że również Liske brał udział w powstaniu styczniowym i w Berlinie toczyło się przeciw niemu śledztwo. Ostatecznie ministerstwo poleciło Wachholzowi prowadzenie zajęć z historii powszechnej i austriackiej w języku polskim w kolejnym semestrze (letnim 1870 r.). Kętrzyński o tej decyzji dowiedział się dopiero w maju tr. ${ }^{29}$

Sprawa przycichła niemal na rok. W tym czasie - na początku 1870 r. - Ksawery Liske ściągnął do Lwowa swego przyjaciela ze studiów, dra Wincentego Zakrzewskiego, rodem z Królestwa Polskiego. Liske miał dość stabilną pozycję we Lwowie. Wykorzystując napiętą atmosferę,

\footnotetext{
${ }^{26}$ Cyt. za: K. Korzon, op. cit., s. 126.

${ }^{27}$ H. Barycz, op. cit., s. 128.

28 Ibidem, s. 129.

29 A. Skrobacki, op. cit., s. 211.
} 
towarzyszącą procesowi polonizacji uczelni, dającą nadzieję - na wzór Krakowa - na rychłą wymianę kadrową, liczył na zatrudnienie tu przyjaciela. Namawiał go na habilitację we Lwowie, sam mocno się w to zaangażował. Zakrzewski w grudniu 1869 r. ukończył monografię pt. Powstanie i wzrost reformacji w Polsce 1520-1572, która miała stać się podstawą awansu naukowego. I znów Liske udał się po pomoc do Kraszewskiego, by ten własnym kosztem opublikował książkę przyjaciela w swojej drukarni w Dreźnie ${ }^{30}$. W liście z 22 marca 1870 r. pisał:

Wielmożny Panie!

Kolega mój z czasów uniwersyteckich, człowiek nieźle piszący a gruntownie wykształcony, Dr Wincenty Zakrzewski, niedawno, na moje zwłaszcza nalegania, przybył do Lwowa, aby się habilitować przy tutejszym uniwersytecie jako docent historii. Przygotował on do druku dość obszerną pracę (200 stron bitego pisma) pod tytułem: Powstanie i wzrost reformacji w Polsce $i$ walka o nia Kościoła katolickiego 1520-1572. Pracę tę ze wszech miar polecić mogę, jest ona i przystępna dla szerszych kół, i sumiennie, krytycznie, ze znajomością źródeł napisana. Udaję się zatem, jako znany już W. Panu osobiście, z zapytaniem do Niego, czybyś W. Pan nie chciał książki tej wydać swoim nakładem. Ponieważ autor użyć jej chce do habilitacji przy tutejszym uniwersytecie, chodzi mu przede wszystkim o to, aby ją można wydrukować jak najprędzej. Honorarium zatem nie żąda żadnego, lecz zadowoli się pewną ilością egzemplarzy, którą niech W. Pan sam oznaczy.

Oczekuję w każdym razie jak najspieszniejszej odpowiedzi, mam zaszczyt pozostać z głębokim uszanowaniem

Wielmożnego Pana uniżony

Dr Xawery Liske

PS Dodaję tylko jeszcze, że praca ta zajęłaby co najmniej 240, 250 stron $^{31}$.

Ostatecznie książka ukazała się w języku polskim nakładem Franciszka Wagnera w Lipsku, wydrukowana u Pillera we Lwowie ${ }^{32} .30$ kwietnia 1870 r. Zakrzewski nostryfikował we Lwowie dyplom doktorski ${ }^{33}$. W styczniu $1871 \mathrm{r}$. chciał przystąpić do habilitacji, niestety bez powodzenia. Zależało mu, aby odbyła się ona w języku polskim, na podstawie pracy wydanej w języku ojczystym, na co nie wyraził zgody prof.

30 J.I. Kraszewski posiadał drukarnię polską w Dreźnie, która pracowała od 10 listopada 1868 do 1 lipca 1871 r., Pamiątka drukarni J. I. Kraszewskiego w Dreźnie 1868-1871, Drezno 1871, s. 5-8.

31 BJ, Dział Rękopisów (dalej: DzR), sygn. 6516 IV, Korespondencja J.I. Kraszewskiego. Seria III. Listy z lat 1863-1887, t. 56: L (Lettner - Lux), k. 245.

${ }^{32}$ W. Zakrzewski, Powstanie i wzrost reformacji w Polsce 1520-1572, Lipsk 1870, ss. 285.

${ }^{33}$ AUJ, WF II 135, Katedra historii powszechnej, Sprawozdanie J. Szujskiego dotyczące oceny kandydatów na katedrę historii powszechnej, b.pag. 
Zeissberg. Relację z przebiegu posiedzenia Rady Wydziału, na której dyskutowano o habilitacji Zakrzewskiego, w sposób bardzo emocjonalny przedstawił Władysław Łoziński na łamach krakowskiego „Czasu” ${ }^{4}$. Lwowski dziennikarz, serdeczny przyjaciel Liskego i Zakrzewskiego, w jak najlepszym świetle przedstawił postać młodego uczonego, nie szczędząc słów krytyki pod adresem austriackich profesorów, głównie Zeissberga, którzy zamykali mu drogę do kariery naukowej i blokowali proces polonizacji lwowskiej uczelni. Nie ulega wątpliwości, że tekst ten miał przedstawić młodego historyka krakowskim uczonym. W wyniku napiętej atmosfery na Uniwersytecie Lwowskim Zeissberg opuścił miasto w semestrze letnim 1871 r., pół roku później wyjechał drugi historyk austriacki - prof. Robert Rössler. Liske, począwszy od semestru zimowego 1871/1872 r., przejął katedrę po Zeissbergu jako profesor nadzwyczajny, rok później jako zwyczajny. Tuż po objęciu katedry Liske rozpoczął procedurę habilitacyjną Zakrzewskiego. Już na pierwszym posiedzeniu Rady Wydziału, 6 października 1871 r. postawiono tę sprawę, referował ją Antoni Małecki, natomiast 12 stycznia 1872 r. na posiedzeniu Rady Wydziału Filozoficznego uniwersytetu Liske przedstawił sprawozdanie komisji oraz poprosił grono profesorów o zatwierdzenie habilitacji przyjaciela z historii powszechnej, co przyjęto jednogłośnie ${ }^{35}$.

Kolejny etap walki o katedrę na UJ rozpoczął się na wieść o planach emerytalnych Walewskiego, kierownika Katedry Historii Powszechnej od $1851 \mathrm{r}$. W połowie grudnia $1870 \mathrm{r}$. Walewski za pośrednictwem Brandowskiego powiadomił Kętrzyńskiego o podjętej decyzji. Zamierzał w kwietniu złożyć podanie o dymisję ${ }^{36} \mathrm{z}$ jednoczesnym zapewnieniem poparcia dla Kętrzyńskiego w ministerstwie przy obsadzie katedry. W piśmie skierowanym do Rady Wydziału Filozoficznego ze stycznia 1871 r. Walewski rzeczywiście wskazał go jako swego następcę ${ }^{37}$.

Informacja ta wywołała wzmożoną korespondencję Szujskiego z Liskem oraz z Zakrzewskim. Po części dotyczyła ona spraw naukowych, w tym zaproszenia obu historyków ze Lwowa na członków Komisji Historycznej Towarzystwa Naukowego Krakowskiego ${ }^{38}$. Osobno Szujski

34 „Czas” 27 I 1871, 22, s. 1.

35 Archiwum Obwodowe we Lwowie, F. 26, op. 7, spr. 154, Protokoły Rady Wydziału Filozoficznego Uniwersytetu Lwowskiego, protokół nr I z 6 X 1871, k. 1; protokół nr VI z 12 I 1872 r., k. $18 \mathrm{v}$.

${ }^{36}$ AUJ, WF II 42, protokół RW z 29 IV 1871, k. 201v.

${ }^{37}$ H. Barycz, op. cit., s. 133.

38 Archiwum Towarzystwa Naukowego Krakowskiego (dalej: ATNK), sygn. 192, dwa listy Liskego do Szujskiego z 21 I 1871: jeden z informacją o przyjęciu członkostwa komisji historycznej TNK, drugi dotyczył spraw naukowych, k. 53, 54; list Zakrzewskiego 
słał listy do Liskego z informacjami i konkretnymi wskazówkami w sprawie konkursu. Oto pierwszy z nich, bez daty (prawdopodobnie koniec stycznia 1871; przed 2 lutego 1871):

\section{Szanowny Panie Ksawery!}

Odpisuję zaraz po otrzymaniu listu. Walewski podaje się na emeryturę i złożył już pisemne zaświadczenie, że dalej wykładać nie będzie. Byłem Panu doniósł o tym, gdyby nie okoliczność, że współcześnie Brandowski wniósł kandydaturę Kętrzyńskiego, jako tę, która raz już przed dwoma laty przeszła przez vota Wydziału, a Wydział wcale się jej nie sprzeciwiał. Sprawa to jeszcze nie załatwiona, ale sądząc $z$ dzisiejszego usposobienia, konkurs rozpisanym nie będzie, bo za Kętrzyńskim będzie zawsze większość głosów. Jeżeli będę widział jakąkolwiek możność wprowadzenia sprawy Pańskiej zrobię co będę mógł i doniosę natychmiast. Listownie radziłbym się odwołać do [Juliana] Dunajewskiego, dziś prorektora, [Stefana] Kuczyńskiego ${ }^{39}$, prodziekana Wydziału Filozoficznego i może i do rektora [Józefa] Kremera. Jeżeli Pan chcesz, abym mógł być dla Pana pożytecznym, przemilcz Pan moje nazwisko i nie podawaj mnie jako źródło. Po trzech kursach ma się na Wydziale jeszcze bardzo słabą podstawę, szczególniej w Wydziale z szczwanych złożonym lisów [wyróżnienie - A.K.]. Za łaskawą odpowiedź na mój list i wezwanie komisji serdecznie dziękuję

Z prawdziwym szacunkiem i przyjaźnią

J. Szujski

Skąd Zeissberg znowu tak się wziął na sprzeczki? Nie byłbym nigdy przypuszczał, aby tak zamiłowany w swych rzeczach, był tak zaciętym? [chodzi o habilitację Zakrzewskiego - A.K. ${ }^{40}$

Lwowski historyk już 1 lutego 1871 r. ponowił swą kandydaturę, jednak zrobił to w dość obcesowy sposób: „Kiedy atoli teraz prof. Walewski podał się do dymisji, a Wydział Filozoficzny nie zamierza o opróżnioną po nim posadę rozpisać konkursu, lecz na zasadzie owego

do Szujskiego z 28 I 1871 z potwierdzeniem przyjęcia członkostwa komisji historycznej, ibidem, k. 55. O staraniach Szujskiego w celu nawiązania współpracy ze środowiskiem lwowskim pisała U. Perkowska, Józef Szujski - pierwszy sekretarz generalny Akademii Umiejętności w Krakowie, w: Amico, socio et viro docto. Księga ku czci profesora Andrzeja Kazimierza Banacha, red. T. Pudłocki, K. Stopka, Kraków 2015, s. 211.

39 Stefan Kuczyński, dziekan WF UJ, w latach 1868/1869 był gorącym orędownikiem powołania Józefa Szujskiego najpierw na Katedrę Historii Powszechnej, następnie, gdy w październiku 1868 r. pojawiła się zapowiedź cesarza o powołaniu nowej Katedry Historii Polskiej, wspierał go w objęciu tej katedry.

${ }^{40}$ BO, DzR, sygn. 11555 I, Korespondencja Ksawerego Liskego od różnych osób 1867-1891, List J. Szujskiego do K. Liskego, b.d., k. 105-105v. 
referatu podać jedynie na kandydata dr Wojciecha Kętrzyńskiego z zupełnym pominięciem mojej osoby", wnosił o wzięcie go pod uwage przy obsadzie katedry ${ }^{41}$.

Ksawery Liske był zdeterminowany w swej walce. Zgodnie z zaleceniem Szujskiego przesłał korespondencje do wskazanych osób, ale też prosił go o osobiste wstawiennictwo u Dunajewskiego. Co więcej, w kolejnym liście tłumaczył Szujskiemu motywy swego działania. Miał głębokie poczucie własnej wartości, wręcz poczucie wyższości, uważał się za profesjonalnego badacza, spełniającego najwyższe standardy w nauce. Nie mógł się pogodzić, że przez stronniczość członków komisji przegrywa rywalizację o katedrę z człowiekiem, który w jego opinii nie spełnia podstawowych kryteriów obowiązujących w nauce, wręcz nie ma kwalifikacji na to stanowisko. W liście z 2 lutego 1871 r. pisał do Szujskiego:

\section{Szanowny Profesorze!}

Serdecznie dziękuję za udzielone wiadomości. Listy napisałem, dzisiaj je wysyłam. Nieskończenie wdzięczny byłbym Szanownemu Profesorowi, gdyby mi Pan zechciał zakomunikować czasu swego, jaki obrót ostatecznie sprawa ta weźmie, skoro przyjdzie do decyzji w Wydziale - ja nie tracę jeszcze nadziei, gdyby się w wydziale znalazł choć jeden człowiek, który by podniósł sprawę moją, a w razie konieczności złożył votum separatum [wyróżnienie oryg.], lub przynajmniej, jak to uczynił w [18]69 Prof. Dunajewski, zwrócił uwagę ministerstwa na stronnicze stanowisko, jakie względem mnie zajmuje prof. Walewski. Nie boję się nieparcjalnych ${ }^{42}$ sądów, które między mną, a Kętrzyńskim muszą wypaść na moją korzyść. Jakież kwalifikacje ma Kętrzyński na profesora wszechnicy z wykładem polskim [wyróżnienie oryg.]? Prócz krótkiej notatki o Pułkawie ${ }^{43}$ nigdy niczego po polsku nie napisał. W języku tym (ani nawet niemieckim) nigdy nie wykładał, mówi po polsku akcentem niemieckim, brakuje mu słów i wyrażeń jakże człowiek taki może wykładać w uniwersytecie. Niech mi Szanowny Profesor wierzy, że gdyby obok mnie stał rywal, któregoby z bezparcjalnego stanowiska można uważać za godnego i odpowiedniego, nie zrobiłbym ani kroku na moją korzyść, pozostawiłbym całą sprawę woli boskiej, tak zaś jak rzeczy stoją, uważam za mój obowiązek, aby wszelkich dołożyć starań, żeby do nominacji Kętrzyńskiego nie przyszło [wyróżnienie -A.K.] [--].

Z uszanowaniem i przyjaźnią Szanownego Profesora uniżony Xawery Liske ${ }^{44}$.

${ }^{41}$ H. Barycz, op. cit., s. 134.

${ }^{42}$ Pełnych, sąd nad całością - w tym znaczeniu nad całością dorobku.

${ }^{43}$ W. Kętrzyński, O paryskim rękopiśmie Pułkawy (Przedruk z „Roczników Towarzystwa Przyjaciół Nauk Poznańskiego”, t. 5), Poznań 1869, ss. 20.

${ }^{44}$ ATNK, sygn. 192, List K. Liskego do J. Szujskiego, Lwów 2 II 1871, k. 62. 
Ostro wyartykułowany zarzut Liskego, jakoby Kętrzyński nie dość dobrze władał językiem polskim i mówił z niemieckim akcentem, był słuszny, choć Barycz zarzucał Liskemu złośliwość w tej mierze. Dwa lata wcześniej przyjaciel Kętrzyńskiego, odradzając mu przyjęcie posady nauczyciela polskich dzieci, tak ocenił jego umiejętności językowe: „Otwarcie muszę Panu jako przyjaciel powiedzieć, że Pan ani nie mówisz, ani nie piszesz poprawnie w języku polskim. Mówię to otwarcie i po przyjacielsku i niech to Pana nie obraża, ale byłoby to pewne impedimentum w domu polskim na nauczyciela domowego" 45 . Słowa te bynajmniej nie zniechęciły Kętrzyńskiego. Wręcz przeciwnie. Wyjechał w Poznańskie, by mieć kontakt z Polakami, przyjął posadę nauczyciela i jednocześnie wytrwale doskonalił kompetencje językowe na podstawie Gramatyki języka polskiego Małeckiego. Nie czuł się jednak pewnie. Podczas pierwszej rywalizacji o katedrę na UJ z Józefem Szujskim, w roku 1869, w liście do zaprzyjaźnionego prof. Brandowskiego tłumaczył, że przesyła swój artykuł naukowy napisany w języku niemieckim, ponieważ nie czuje się jeszcze na siłach pisać tego typu prac po polsku. Brandowski zwracał wówczas uwagę krakowskim profesorom na „kaszubską” wymowę Kętrzyńskiego ${ }^{46}$. Zatem trudno mówić tu o złośliwości ze strony Liskego, niemniej przyznać należy, że postępował bezwzględnie.

Pisma, które wysyłał Liske do krakowskich profesorów, a zwłaszcza ich ton, zniechęciły ich zupełnie do kandydata ze Lwowa. Wprawdzie w kolejnych listach do Szujskiego pytał o losy tej sprawy ${ }^{47}$, ale ostatecznie otrzymał „cierpką” odpowiedź od dziekana Wydziału Filozoficznego UJ Karlińskiego ${ }^{48}$. Sprawa znów przygasła na kilka miesięcy.

Gdy jednak ministerstwo w lipcu 1871 r. przeniosło prof. Walewskiego w stan spoczynku i zwróciło się do Rady Wydziału o wskazanie kandydata na zwolnioną katedrę, podjęto 22 lipca uchwałę, by rozpisać konkurs na to stanowisko z terminem do 1 października 1871 r., by pozyskać nowe osoby ${ }^{49}$. Liske bez szans na objęcie katedry w Krakowie zrezygnował już ze starań, tym bardziej że od nowego semestru przejmował Katedrę Historii Powszechnej we Lwowie po Zeissbergu. Natomiast dołożył wszelkich starań, by Katedra Historii Powszechnej w Krakowie została powierzona Zakrzewskiemu. Ze względu na okres wakacyjny, informacja

${ }^{45}$ List Włodzimierza Wolniewicza do W. Kętrzyńskiego z 31 XII 1867, cyt. za: K. Korzon, op. cit., s. 112 .

46 Ibidem, s. 120

47 ATNK, sygn. 192, list K. Liskego do J. Szujskiego, Lwów 14 II 1871, k. 66.

${ }^{48}$ H. Barycz, op. cit., s. 134.

${ }^{49}$ AUJ, WF II 42, Protokół z 22 VII 1871, k. 214. 
o konkursie opublikowana została w prasie dopiero 18 września. Czasu było dramatycznie mało.

Wincenty Zakrzewski przebywał wówczas na urlopie w Warszawie. Pod wpływem informacji od Szujskiego i Liskego przystąpił do konkursu, a podanie złożył w ostatnim momencie. Niestety jego dokumentacja była niekompletna, gdyż, jak tłumaczył, przebywał za granicą, a wszelkie materiały i publikacje znajdowały się we Lwowie, w miejscu jego zamieszkania. Zobowiązał się więc, że niezwłocznie po powrocie dośle wymagane dokumenty ${ }^{50}$. Do konkursu oprócz Kętrzyńskiego i Zakrzewskiego zgłosili się jeszcze uczeń Zeissberga Karol Benoni oraz Teodor Stahlberger, profesor gimnazjum św. Anny, ale tylko dwaj pierwsi byli brani po uwagę przez komisję. Tym razem głos decydujący w komisji należał do Szujskiego i Wachholza, obaj przychylni byli Zakrzewskiemu.

Ten zaś, w przeciwieństwie do Liskego, wystosował bardzo ostrożne i wyważone podanie, godził się na wszelkie warunki, nawet suplenturę, czyli zastępstwo profesury, zobowiązał się także do przeprowadzenia przewodu habilitacyjnego, by wykazać, że ma predyspozycje do wykładów. Śledząc przebieg konkursu można odnieść nieodparte wrażenie, że Szujski drobnymi krokami, konsekwentnie torował mu drogę do katedry. Trwało to równo rok. Najlepiej świadczy o tym korespondencja obu historyków oraz protokoły rad wydziału.

Początkowo sprawa obsadzenia katedry miała zostać rozstrzygnięta na posiedzeniu Rady Wydziału 20 października 1871 r., o czym świadczy jeden z punktów porządku obrad uwzględniony w zaproszeniu na posiedzenie, jednak w protokole posiedzenia nie ma o tym wzmianki ${ }^{51}$. Najprawdopodobniej Szujski jako sprawozdawca komisji nie zdążył przygotować oceny dorobku kandydatów, ponieważ od 14 września do 17 października 1871 r. przebywał we Lwowie, trwała bowiem sesja sejmu krajowego, którego był posłem. Sprawie obsadzenia Katedry Historii Powszechnej poświęcono osobną radę 25 listopada 1871 r. Szujski w imieniu własnym i Wachholza przedstawił ocenę kandydatów. Pod względem dorobku naukowego, kompetencji zawodowych i językowych lepiej wypadł Zakrzewski. Szujski podkreślił szczególnie jego wykształcenie, wyliczając znakomite nazwiska jego profesorów, pod okiem których zdobywał wiedzę, docenił również kwerendy archiwalne w bibliotekach warszawskich, w tym znajomość Metryki Koronnej. Do konkursu Zakrzewski przedłożył trzy prace: habilitacyjną - 0 wstapieniu Władysława III na tron węgierski (praca po niemiecku); Powstanie i wzrost reformacji w Polsce

\footnotetext{
50 AUJ, WF II 135, Podanie z 30 IX 1871, b.pag.

${ }^{51}$ AUJ, WF II 42, k. 218.
} 
(1520-1572); Stosunki Stolicy Apostolskiej z Iwanem Groźnym, carem i wielkim księciem moskiewskim (praca w rękopisie). Wszystkie otrzymały pozytywne ceny. Szujski podkreślił, że Zakrzewski w swych pracach wykazał zdolności krytyczne oraz dobrą szkołę historyczną, wyczerpał źródła, w tym nieznane rękopisy i literaturę, udowodnił, że poważnie traktuje naukę ${ }^{52}$.

Kętrzyński również otrzymał pozytywną opinię. Obydwu jednak kandydatom komisja zarzuciła, że nie mają doświadczenia w głoszeniu wykładów oraz nie mają dorobku w zakresie historii starożytnej (Kętrzyński był mediewistą, Zakrzewski nowożytnikiem). Wobec nieopanowania przez nich historii starożytnej wysunięto projekt przeprowadzenia przez obydwóch habilitacji z tego zakresu. Jednocześnie zaproponowano, by obaj kandydaci - po przeprowadzeniu habilitacji - otrzymali posade zastępców profesora $\mathrm{z}$ wynagrodzeniem połowy pensji profesora zwyczajnego. Odpowiadało to wynagrodzeniu płatnego docenta ${ }^{53}$. Ta propozycja od razu stawiała Kętrzyńskiego na straconej pozycji. Zakrzewski, młodszy o sześć lat i bardziej zaradny, złożył gotowość przeprowadzenia habilitacji na życzenie komisji, Kętrzyński zaś nie zamierzał poddawać się tej procedurze. W jego obronie stanął prof. Czerwiakowski, który 2 grudnia złożył na ręce dziekana votum separatum.

W tej sytuacji 6 grudnia $1871 \mathrm{r}$. dziekan zwołał nowe posiedzenie wydziału . Po dłuższej dyskusji podjęto decyzję, by anulować uchwałę z 25 listopada i ponownie rozpatrzyć sprawę, powołując nową komisję w składzie: Wachholz, Szujski, Kuczyński, Czerwiakowski, Brandowski oraz Stanisław Tarnowski. Czterech jej członków przychylnych było kandydaturze Zakrzewskiego. Jednocześnie komisja zwróciła się do kilku historyków przebywających za granicą z propozycją objęcia katedry w Krakowie. Skontaktowano się z m.in. z ks. Walerianem Kalinką (był w Rzymie), Romanem Wyzińskim (byłym prof. Uniwersytetu Moskiewskiego), Adolfem Pawińskim (prof. nadzw. historii powszechnej Cesarskiego Uniwersytetu w Warszawie) - wszyscy odmówili ${ }^{54}$.

Procedura konkursowa przedłużała się. Zakrzewski nie miał żadnych informacji z Krakowa, co potęgowało jego zniecierpliwienie i niepokój. W październiku 1871 r. spotkał się z Szujskim we Lwowie. Padły wówczas $\mathrm{z}$ ust profesora UJ pewne obietnice wobec Zakrzewskiego, ale można przypuszczać, że Szujskiemu zależało na dyskrecji, nie chciał, by oficjalnie uważano go za sprzymierzeńca jednej ze stron. Zakrzewski jednak

${ }^{52}$ AUJ, WF II 135, Katedra historii powszechnej, Sprawozdanie J. Szujskiego dot. oceny kandydatów na katedrę historii powszechnej, b.pag.

53 AUJ, WF II 42, Protokół z 25 XI 1871, k. 222-223.

${ }^{54}$ H. Barycz, op. cit., s. 138. 
zasypywał Szujskiego listami, za każdym razem powołując się na obiecaną protekcję. Szukał różnych pretekstów, by wysłać list i przy okazji dopytać o losy konkursu. W liście z 1 listopada 1871 r. pisał np.: „Ufając łaskawemu przyrzeczeniu Szanownego Pana zawiadomić mnie o mojej kandydaturze krakowskiej i jej widokach oczekuję spełnienia go z cierpliwością w nadziei, że w ciągu paru tygodni zapewne coś o tym usłyszę od Niego", następnie prosił Szujskiego o pomoc w wydaniu pracy Stosunki stolicy apostolskiej z Iwanem Groźnym w „Przeglądzie Polskim”, którego Szujski był współredaktorem. Ponownie przywołał rozmowę: „Może sobie Szanowny Pan Profesor przypomina, żeśmy tutaj mówili o tym". Znamienne jest ostatnie zdanie listu. W postscriptum Zakrzewski delikatnie przypomina Szujskiemu o drobnym zobowiązaniu wobec autora listu: „Czy przydały się Sz. P. na co wzięte ode mnie dokumenta z Metryki [Koronnej - A.K.]"?55.

Szujski jednak na ten list nie odpowiedział. Zakrzewski szukał zatem innych źródeł informacji. Ważny sygnał otrzymał od Karola Estreichera już dwa dni po posiedzeniu Rady Wydziału. Błyskawicznie napisał do Szujskiego:

Przed niedużym czasem pisałem był do pana Estreichera z prośbą o niektóre objaśnienia bibliograficzne. Właśnie otrzymuję odpowiedź, w której także w przypisku donosi mi, jako o rzeczy naturalnie wielce mnie obchodzącej, że w tych dniach odbyła się sesja wydziału rozstrzygająca o obsadzie katedry historii, że wprawdzie nie wie co tam stawało, lecz podobno p. Kętrzyński miał większe szanse. Naturalnie Szanowny Pan Prof. musi dokładnie wiedzieć jak to było, dlatego powołując się za łaskawe Jego przyrzeczenie w Lwowie mi uczynione, donieść mi o rozstrzygnieniu, choćby niekorzystnym i z tym i lepiej będzie donieść prawdę choćby niemiłą.

Zakrzewski przekonywał Szujskiego, że wprawdzie rozpoczął starania o docenturę na Uniwersytecie Lwowskim, otwarto mu tutaj procedurę habilitacyjną, ale zależy mu na konkretnej informacji, by w razie niepowodzenia w Krakowie mógł „rozpatrzeć się zawczasu o jakie inne zajecie, na co potem nie będzie już pora, a to na samej li docenturze, o którą się tu podałem, trudno poprzestać" 56 .

Kolejnym informatorem Zakrzewskiego był sam Kętrzyński, który w drodze do Lwowa zatrzymał się w Krakowie i uzyskał tam obszerne

${ }^{55}$ BO, DzR, sygn. 5770 I, Korespondencja Szujskiego: list W. Zakrzewskiego do J. Szujskiego, Lwów 1 XI 1871, k. 100,100v.

${ }^{56}$ BO, DzR, sygn. 5770 I, Korespondencja Szujskiego: list W. Zakrzewskiego do J. Szujskiego, Lwów 27 XI 1871, k. 101. 
informacje o ustaleniach wydziału z 6 grudnia w sprawie konkursu, od przychylnego mu Brandowskiego. Po przyjeździe do Lwowa, w celu przeprowadzenia kwerendy na potrzeby Aktów Tomicianów w Ossolineum, dobroduszny Kętrzyński podzielił się z Zakrzewskim swoją wiedzą, a ten niezwłocznie przystąpił do działania.

18 grudnia wystosował długi list do Szujskiego, w którym wytykał mu nadmierną ostrożność w zachowaniu tajemnicy, choć wydaje się, że dla utrzymania tylko pozorów. Zakrzewski oburzał się na bezzasadne, jego zdaniem, zarzuty stawiane przez komisję wobec kandydatów. Pisał:

\section{Sz. P. Profesorze}

Jakkolwiek Szanowny Pan nie zalecał mnie uwiadomić o rezultacie narady Wydziału co do obsadzenia katedry historii, jednakowoż rzecz ta nie musiała być zachowaną $\mathrm{w}$ tajemnicy, skoro naraz z kilku stron wieści o pierwotnym postanowieniu mnie doszły. Bliższych zaś szczegółów głównie udzielił mi szanowny mój współzawodnik dr Kętrzyński, którego kilkudniowy tu pobyt dał mi sposobność do zrobienia jego znajomości dla mnie pożądanej wielce. Zewsząd tedy słyszę, że najważniejszym zarzutem, jaki mi czyniono był, iż nie pisałem, ani nie znam historii starożytnej. Zarzut co prawda dosyć dziwny: [Leopold] Ranke, uznany za największą znakomitość historyczną w Niemczech nie mało by się pewno zdziwił, że mimo wszystko nie posiada dostatecznych kwalifikacji na profesora w Krakowie, bo - o historii starożytnej nie pisał [wyróżnienie A.K.]. Ale mnie nie orzekającemu o kwalifikacjach, lecz przedstawić je mającemu, nie przystało dyskutować o tym; nie tylko mi chodzi o to, że zarzut jest i ile dotyczący nieznajomości historii starożytnej nawet nie straszny. Zgłaszając się do konkursu przedstawiłem tylko te moje prace, o których mi się zdawało, że w czym bądź do poznania jakiejś nowej strony historii się przyczyniają. Żeby zaś w historii starożytnej tylokrotnie i przez tylu już uprawianą coś nowego wynaleźć, na to potrzeba obrać ją sobie za przedmiot specjalnych długich studiów. Że zamiast to uczynić, raczej ku historii polskiej się zwróciłem, tego sądzę Szanowny Pan Profesor chyba mi za złe nie bierze. Ale jak powiedziałem, zarzut ten i niesłuszny: pracowałem nawet dosyć długo nad historią starożytną i dla własnej wprawy.

Zakrzewski przedłożył komisji dwie prace seminaryjne z czasów studenckich, które nieco poprawił. Jak zastrzegał: „nie mogą rościć żadnych pretensji do nowych odkryć", ale świadczą o znajomości źródeł. Jedna, z historii starożytnej greckiej, dotyczyła wojen peloponeskich, druga, z historii rzymskiej, nosiła tytuł: Agrypina żona Germanika i była przeznaczona do druku na łamach warszawskiego pisma „Niwa”. Tłumaczył się również z braku prac na temat historii starożytnego Wschodu: 
„Za to znajomością z pierwotnych źródeł dziejów wschodu, Indii lub narodów semickich, niestety pochwalić się nie mogę, bo sanskrytu ani nawet hebrajskiego nie znam. Lecz pocieszam się nadzieją, że chyba te znajomości nie są niezbędnym warunkiem dla historyka".

W dalszej części listu Zakrzewski wszedł w polemikę z Szujskim wobec innego zarzutu, postawionego mu w ocenie dorobku:

Szanowny Pan Profesor wybaczy, że sobie jeszcze jedną uwagę zrobić pozwolę. Według dochodzących mnie wieści, podobno Szanowny Pan w swej o mych pracach opinii przyznawał im charakter syntetyczny, lecz odmawiał analitycznego. W głównej zasadzie muszę przyznać, że z mojej strony to określenie bardzo trafnym znajduję. Zresztą zapewne Szanownego Pana Profesora niewiele moje zdanie obchodzi, lecz widzę z tego, że tej mojej pracy, którą w rękopisie złożyłem o stosunku Rzymu do Moskwy, Szanowny Pan Profesor uwzględnić nie chciał. W niej bowiem niektóre części, mianowicie rozdział I i II są najzupełniej analityczne: chyba żebym sam się całkiem na tym nie znał, jeżeli się mylę. Że inne części tejże pracy, jako też inne moje mają rzeczywiście tamten charakter, ta o ile mi się zdaje, z natury przedmiotu wynikać musiał, a po części i z rodzaju naszej publiczności. Bo dla analizy ścisłej, a więc zazwyczaj w formie mniej dostępnej, tylko badaczy interesującej, niewiele by znalazł czytelników, a już nakładcy chyba żadnego.

Jak by tego było mało, Zakrzewski pod koniec listu zapowiedział rychłą wizytę w Krakowie, by osobiście dopilnować sprawy swej kandydatury ${ }^{57}$.

Obaj kandydaci przedłożyli do oceny drobne rozprawki - prace seminaryjne z czasów studiów. Ocenił je Brandowski, a Wydział wysłał do ministerstwa wraz ze sprawozdaniem ${ }^{58}$. Jakkolwiek zarzuty dotyczące nieznajomości historii starożytnej były dla Zakrzewskiego nielogiczne, wynikały jednak ze statutu seminarium historycznego UJ z 1861 r. autorstwa Walewskiego. Profesor podkreślił, że podstawowym zadaniem seminarium jest przygotowanie nauczycieli do pracy w szkołach gimnazjalnych, stąd główny nacisk położył na historię starożytną, której sam poświęcał wiele miejsca podczas zajęćs ${ }^{59}$. Na Wydziale Filo-

${ }^{57}$ BO, DzR, sygn. 5770 I, Korespondencja Szujskiego: list W. Zakrzewskiego do J. Szujskiego, Lwów 18 XII 1871, k. 105-107v.

${ }^{58}$ AUJ, WF II 135, Katedra historii powszechnej. Komisja historyczna. Sprawozdanie z dwóch prac Kętrzyńskiego i jednej Zakrzewskiego, Kraków 27 I 1872, referent Brandowski, b.pag.

${ }^{59}$ Kronika UJ, s. 91; M. Stinia, Biblioteka Seminarium Historycznego Uniwersytetu Jagiellońskiego w latach 1873-1918, w: Virtuti et ingenio. Księga pamiatkowa dedykowana profesorowi Julianowi Dybcowi, red. A.K. Banach, Kraków 2013, s. 466-467. 
zoficznym UJ funkcjonowało seminarium historyczne w dwóch oddziałach: historii powszechnej i austriackiej. Zwycięzca konkursu, jako profesor historii powszechnej, otrzymywał jednocześnie kierownictwo właściwego oddziału seminarium historycznego. Była to bardzo prestiżowa funkcja ${ }^{60}$.

Zabiegi Zakrzewskiego okazały się skuteczne. Niewątpliwie pomogła mu również habilitacja przeprowadzona we Lwowie z historii powszechnej oraz propozycje wykładów, które zgłosił na semestr letni w roku akademickim 1871/1872 na Uniwersytecie Lwowskim. Zaproponował dwa tematy: dzieje Polski za czasów Zygmunta Augusta, w latach 1540-1572 (trzy godz. tygodniowo) oraz - nieprzypadkowo - historię starożytną, część pierwsza: dzieje wschodu (dwie godz. tygodniowo) ${ }^{61}$.

Na posiedzeniu Rady Wydziału 8 marca 1872 r. Szujski, referując stanowisko komisji, postąpił wbrew jej wcześniejszym ustaleniom i zupełnie pominął Kętrzyńskiego. Zakrzewski został przedstawiony jako jedyny kandydat Wydziału na profesora nadzwyczajnego historii powszechnej. W toku dyskusji Brandowski, członek komisji oceniającej, wyraził sprzeciw wobec tak sformułowanego wniosku i zaproponował, by zgłaszając obu kandydatów do Wiednia, jako pierwszego wysunąć Zakrzewskiego, na drugiej zaś pozycji umieścić Kętrzyńskiego. W tej sytuacji przeprowadzono głosowanie. Przy trzynastu głosach za oraz dwu przeciwnych (Brandowski i Henryk Suchecki) Zakrzewski wygrał z Kętrzyńskim. I to on dostał rekomendację rady do objęcia katedry historii powszechnej, przesłaną do ministerstwa ${ }^{62}$.

Taki obrót sprawy był możliwy dzięki kuluarowym działaniom. Szujski potrafił zjednać sobie wpływowych profesorów z byłym rektorem Dunajewskim i dziekanem Kuczyńskim oraz przyjacielem Stanisławem Tarnowskim na czele. Sprzyjał mu również Wachholz. Zresztą pozycja Szujskiego w Uniwersytecie w tym czasie była już zupełnie inna niż jeszcze dwa lata wcześniej. Jako czołowy przedstawiciel krakowskich konserwatystów, poseł na sejm krajowy, sekretarz i sprawozdawca sejmowej komisji edukacyjnej, członek Rady Szkolnej Krajowej, czołowa postać w Towarzystwie Naukowym Krakowskim, a następnie w Akademii Umiejętności, mógł sobie dobierać współpracowników, z czasem stał się niekwestionowanym liderem na Wydziale Filozoficznym.

${ }^{60}$ M. Stinia, Uniwersytet Jagielloński w latach 1871-1914. Modernizacja procesu nauczania, Kraków 2014, s. 209-211.

${ }^{61}$ Archiwum Obwodowe we Lwowie, F. 26, op. 15, spr. 716, Absolutoria Wydziału Filozoficznego 1870-1880, k. 32, 48.

${ }^{62}$ AUJ, WF II 42, Protokół z 8 III 1872, k. 231, 231v. 
Wydawać by się mogło, że sprawa obsadzenia katedry została już przesądzona, członkowie Rady Wydziału zrobili wszystko co mogli, pozostawało tylko czekać na nominację z Wiednia. Ta jednak nie nadchodziła. Zaniepokojony Szujski zasugerował Zakrzewskiemu, by przypomniał o sobie krakowskim uczonym, ale i ministerstwu, które opóźniało decyzję w tej sprawie. Polecił mu, aby przesłał na ręce dziekana wydziału Kuczyńskiego swą kolejną publikację, bardzo krytyczną recenzję wydawnictwa źródłowego, która niedawno ukazała się drukiem na łamach warszawskiego pisma „Niwa” pt.: Codex diplomaticus Tinecensis ${ }^{63}$. Zakrzewski 12 maja przesłał ją na ręce dziekana, tłumacząc, że „dopóki ta sprawa nie jest jeszcze stanowczo rozstrzygnięta, to obowiązkiem jest moim przesyłać wszelkie w tym czasie dokończone moje prace, mogące pod jakim bądź względem być za dowód, czyli posiadam odpowiednie uzdolnienie do zajęcia katedry" ${ }^{4}$.

Jednocześnie z listem do dziekana Zakrzewski wystosował list do Szujskiego, z którego dowiadujemy się, że krakowski profesor zalecił mu także osobistą interwencję $\mathrm{w}$ namiestnictwie galicyjskim, by tam przyspieszyć wysłanie podpisanych wniosków Rady Wydziału UJ do Ministerstwa Wyznań i Oświecenia w Wiedniu. Oczywiście Zakrzewski wypełnił zadanie, co skrupulatnie zrelacjonował w liście, prosząc jednocześnie swego protektora o jego osobiste wstawiennictwo w Wiedniu w tej sprawie ${ }^{65}$.

Szujski uczynił zadość prośbie Zakrzewskiego. Przygotował obszerną recenzję ostatniej jego publikacji i wraz z tekstem przesłał ją do Wiednia jako załącznik do wcześniejszej dokumentacji ${ }^{66}$.

Dekret nominacyjny dla Zakrzewskiego wystawiono w lipcu $1872 \mathrm{r}^{67}$, kiedy ten przebywał na wakacjach za granicą. Z początkiem sierpnia ponaglany był listami od Szujskiego, Liskego i Władysława Łozińskiego, przypominającymi o konieczności złożenia przysięgi w namiestnictwie. I znów Zakrzewski korzystał z pomocy przyjaciół, głównie Łozińskiego,

${ }^{63}$ W. Zakrzewski, Codex diplomaticus Tinecensis. Kodeks dyplomatyczny tyniecki, wydany staraniem i nakładem Zakładu Narodowego imienia Ossolińskich. Cz. I-sza, XIII-ty i XIV-ty wiek, Lwów, w drukarni Zakładu Narodowego im. Ossolińskich 1871. 4-o, str. VII, 198, w: „Niwa. Dwutygodnik Naukowy, Literacki i Artystyczny” 1, 1872, 1, nr 6, s. 137-141; nr 7, s. 172-174; nr 8, s. 195-197.

${ }^{64}$ BO, DzR, sygn. 5770 I, Korespondencja Szujskiego: list W. Zakrzewskiego do S. Kuczyńskiego, Lwów 8 V 1872, k. 109.

65 BO, DzR, sygn. 5770 I, Korespondencja Szujskiego: list W. Zakrzewskiego do J. Szujskiego, Lwów 8 V 1872, k. 113-115.

${ }^{66}$ AUJ, WF II 135, Katedra historii powszechnej. Ocena pracy W. Zakrzewskiego Codex diplomaticus tinecensis. Kraków 12 VI 1872, referent Szujski, b.pag.

${ }^{67}$ BJ, DzR, sygn. 10062 IV, Korespondencja Władysława Łozińskiego, t. 17, s. 96, 96v. 
który pomógł mu w formalnościach urzędowych oraz zorganizował przeprowadzkę do Krakowa. Pracę rozpoczął od semestru zimowego roku akademickiego 1872/1873 jako profesor nadzwyczajny historii powszechnej. Został również dyrektorem oddziału seminarium historycznego ${ }^{68}$.

Trudno orzec jednoznacznie, co powodowało Szujskim, kiedy walczył o kandydaturę Ksawerego Liskego, a następnie Wincentego Zakrzewskiego przeciw Kętrzyńskiemu - czy wyłącznie kryteria naukowe, czy może podobieństwa charakterologiczne lub poglądy polityczne? Faktem jest, że o sukcesie danego kandydata decydowała pozycja jego „promotora". W przypadku Liskego pozycja Szujskiego na uniwersytecie była słaba, co sam Szujski podkreślał w swym liście. Pracowali jeszcze na wydziale dwaj historycy starego pokolenia. Zresztą Liske nie pomagał swoim postępowaniem. Od razu dał się poznać jako człowiek niezależny, pewny siebie, pełen ambicji, ale również bardzo zasadniczy i pryncypialny wobec spraw naukowych. Być może Szujski faktycznie nie miał możliwości przeprowadzenia tej kandydatury, ale możliwe jest również, że widział w nim niebezpiecznego konkurenta na Wydziale, trudnego we współpracy.

Z czasem Szujski stawał się coraz bardziej skuteczny, samodzielny, szybko wszedł w krwioobieg uniwersytetu. Nie bez znaczenia była powolna wymiana pokoleniowa wykładowców na Wydziale Filozoficznym; jednym z najważniejszych sojuszników Szujskiego w tym czasie był Tarnowski. Po odejściu Walewskiego i przy planowanej niebawem emeryturze Wachholza, Szujski mógł sobie dobierać współpracowników. Zakrzewski zaś dał się poznać jako ambitny historyk, niezwykle zdeterminowany w dążeniu do celu, reprezentujący profesjonalizm i krytycyzm w badaniach historycznych. Pod względem charakteru znacząco różnił się od Liskego, co niewątpliwie procentowało - był bardziej uległy, stonowany, umiał się dostosować do sytuacji, był pełen uznania dla autorytetu Szujskiego. Młodszy od Liskego o sześć lat, od Szujskiego o dziewięć, nie stanowił dla niego zagrożenia. Wydaje się również, że Zakrzewski bliższy był Szujskiemu pod względem poglądów politycznych. Sympatyzował bowiem z konserwatystami krakowskimi, wspierał rozwój krakowskiej szkoły historycznej. Kętrzyński natomiast nie odcinał się od powstania styczniowego, był wręcz dumny ze swej postawy, angażował

${ }^{68}$ Kronika UJ, s. 92-94. Nowy statut w 1877 r. wprowadził zmianę w organizacji seminarium - dwa oddziały zostały zamienione na dwie sekcje: metodologiczną i dydaktyczną. Ostatnia skupiała się na zapewnieniu przygotowania nauczycieli do wykładu historii w szkołach średnich; sekcja metodologiczna - przygotowywała słuchaczy do samodzielnych badań naukowych. 
się w krzewienie polskości na Mazurach, w duchu pozostawał romantykiem. Poza tym był człowiekiem niezwykle dobrodusznym, nie narzucał się swoją osobą, wręcz przeciwnie, chyba nie potrafił walczyć o swoją pozycję, wycofywał się w obliczu niepowodzeń, ale też nie żywił urazy do osób, które wobec niego nie zawsze postępowały uczciwie.

Zakrzewski bardzo wiele zawdzięczał Szujskiemu. Liske również mimo że nie uzyskał katedry w Krakowie. Bardzo szybko zacieśniły się relacje między tymi historykami - w listach ton oficjalny ustąpił miejsca serdecznej zażyłości, podjęli współpracę naukową, wspierali się wiedzą i materiałami źródłowymi, zachowywali najwyższe standardy w badaniach historycznych. Wszyscy oni reprezentowali historyzm w nauce, byli uczniami lub, jak Szujski, uważali się za wychowanków niemieckiej szkoły historycznej - to było spoiwem cementującym relacje i wspólne cele naukowe ${ }^{69}$. Józef Szujski współtworzył krakowską szkołę historyczną, a Wincenty Zakrzewski szybko zbudował swoją pozycję naukową na uniwersytecie $^{70}$. Obaj przyczynili się do rozwoju studium historycznego na Uniwersytecie Jagiellońskim, odpowiadali za profesjonalizację badań, zmodernizowali proces edukacji, rozwijali infrastrukturę naukową w ramach uczelni (seminarium, biblioteka seminaryjna; Akademia Umiejętności) ${ }^{71}$. Ksawery Liske stworzył szkołę dydaktyczną na Uniwersytecie Lwowskim, spod jego skrzydeł wyszło ponad 120 historyków gruntownie przygotowanych do zawodu nauczyciela, w tym kilku wybitnych uczonych $^{72}$, zadbał o profesjonalną infrastrukturę naukową ${ }^{73}$. Każdy z nich zapisał się trwale w dziejach polskiej historiografii, każdy miał wielkie zasługi we wprowadzeniu nowoczesnych standardów w nauce historycznej i każdy z nich swą karierę naukową zawdzięczał życzliwej pomocy wpływowych protektorów.

${ }^{69}$ K. Zamorski, op. cit., s. 51-59.

${ }^{70}$ M. Stinia, Uniwersytet Jagielloński, s. 465-476; J. Pisulińska, Polska XVI wieku w pracach historycznych Wincentego Zakrzewskiego, w: Wspólne dziedzictwo. Rzeczpospolita Obojga Narodów w polskiej, litewskiej i ukraińskiej historiografii XIX i XXI wieku, red. M. Hoszowska, J. Pisulińska, P. Sierżęga, L. Zaszkilniak, Rzeszów 2019, s. 130-140.

${ }^{71}$ J. Maternicki, Historia i życie narodu, s. 134-135, 144-157.

72 A. Kawalec, Seminarium historii powszechnej Ksawerego Liskego. Lista studentów i prac seminaryjnych, „Galicja. Studia i Materiały” 1, 2015, s. 358-377.

${ }^{73}$ J. Maternicki, Epoka Ksawerego Liskego (1871/72-1891/92). Dydaktyka i badania, w: idem, Złote lata historiografii polskiej we Lwowie, Rzeszów 2015, s. 91-124; idem, Historia i życie narodu, s. 229-233; A. Kawalec, Lwowskie studium historyczne 1869-1918, w: Historia w Uniwersytecie Lwowskim. Badania i nauczanie (do 1939 roku), red. J. Maternicki, J. Pisulińska, L. Zaszkilniak, Rzeszów 2016, s. 99-145. 


\section{Streszczenie}

Celem niniejszego tekstu jest ukazanie warunków funkcjonowania nauki historycznej na Uniwersytecie Jagiellońskim, ale też na Uniwersytecie Lwowskim, w początkowych latach funkcjonowania autonomii galicyjskiej. W tym przełomowym okresie miała miejsce ostra walka o polonizację uczelni, o pokoleniową wymianę kadrową związaną z wprowadzeniem nowych standardów w nauce. $\mathrm{Na}$ przykładzie początków karier naukowych czołowych przedstawicieli historiografii polskiej XIX w.: Józefa Szujskiego, Ksawerego Liskego, Wincentego Zakrzewskiego oraz Wojciecha Kętrzyńskiego poznajemy okoliczności powoływania profesorów na katedry uniwersyteckie, którym towarzyszyły skomplikowane zabiegi, zakulisowe walki i intrygi, słowem twarda i często bezkompromisowa rywalizacja w imię szczytnych wartości, którymi były profesjonalizacja badań naukowych oraz rozwój nowoczesnej historiografii. Przy okazji, dzięki prywatnej, często poufnej korespondencji, poznajemy mistrzów historiografii od czysto ludzkiej strony. Odsłaniamy ich charaktery, postawy, ambicje, zachowania nie zawsze etycznie jednoznaczne.

\section{At the Beginnings of Modernization of the Historical Study at the Jagiellonian University. The Efforts of Ksawery Liske and Wincenty Zakrzewski for the Department of General History at the Jagiellonian University}

The article aims to present the operating conditions of historical studies and scholarship at the Jagiellonian University, but also at the University of Lwów (Lviv, Lemberg) in the early years of the Galician autonomy. During this breakthrough period, there was a bitter struggle for the Polonization of the university and a generational change of its workforce relating to the introduction of new standards in sciences. Using the example of leading historians of the nineteenth century, Józef Szujski, Ksawery Liske, Wincenty Zakrzewski, and Wojciech Kętrzyński, it has been possible to establish the beginnings of their university careers, the circumstances of their appointments to university chairs, accompanied by complicated endeavours, behind-the-scenes fights and intrigues, in short - tough and often uncompromising rivalry in the pursuit of noble ends, that is, the professionalization of historical research and the development of modern historiography. On this occasion, thanks to their private, often confidential correspondence, we can gain a better insight into the human side of the leading masters of Polish historiography at that time. We reveal their characters, attitudes, aspirations, and behaviour, which was not always ethically unambiguous. 


\section{Bibliografia}

Achremczyk Stanisław, Wojciech Kętrzyński historyk, bibliotekarz, poeta, Muzeum im. Wojciecha Kętrzyńskiego, Kętrzyn 2008.

Baczkowski Krzysztof, W służbie dworu habsburskiego. Antoni Walewski (1805-1876), „Zeszyty Naukowe Uniwersytetu Jagiellońskiego” 1279, „Prace Historyczne” 2005, 132, s. 99-108.

Balzer Oswald, Zakrzewski Wincenty, Finkel Ludwik, Ćwikliński Ludwik, Sawczyński Henryk, Hordyński Zdzisław, Xawery Liske. Zarys biograficzny, „Kwartalnik Historyczny" 5, 1891, s. 466-548.

Barycz Henryk, Krakowskie przygody Wojciecha Kętrzyńskiego, w: Wśród gawędziarzy pamiętnikarzy $i$ uczonych galicyjskich. Studia i sylwety z życia umysłowego Galicji w XIX w., t. 2, Wydawnictwo Literackie, Kraków 1963, s. 117-146.

Chojnacki Władysław, Wojciech Kętrzyński a Mazury, „Rocznik Zakładu Narodowego imienia Ossolińskich" 3, 1948, s. 1-57 [529-585].

Grabski Andrzej Feliks, Polityka i Katedra Historii Polskiej, w: idem, Troski i nadzieje. Z dziejów polskiej myśli społecznej i politycznej XIX w., Wydawnictwo Łódzkie, Łódź 1981.

Julkowska Violetta, Historia dla wyobraźni. Recepcja i interpretacja pisarstwa historycznego Karola Szajnochy, Wydawnictwo Poznańskie, Poznań 2010.

Julkowska Violetta, Ksawery Liske (1838-1891), w: Złota ksiega historiografii lwowskiej XIX i XX wieku, red. Jerzy Maternicki, Leonid Zaszkilniak, Wydawnictwo Uniwersytetu Rzeszowskiego, Rzeszów 2007, s. 183-200.

Kawalec Agnieszka, Lwowskie studium historyczne 1869-1918, w: Historia w Uniwersytecie Lwowskim. Badania i nauczanie (do 1939 roku), red. Jerzy Maternicki, Joanna Pisulińska, Leonid Zaszkilniak, Wydawnictwo Uniwersytetu Rzeszowskiego, Rzeszów 2016, s. 99-145.

Kawalec Agnieszka, Seminarium historii powszechnej Ksawerego Liskego. Lista studentów i prac seminaryjnych, „Galicja. Studia i Materiały” 1, 2015, s. 358-377.

Kawalec Agnieszka, Z Wielkopolski do Lwowa - w pogoni za realizacja marzeń. Przypadek Ksawerego Liskego w świetle korespondencji, „Galicja. Studia i Materiały” 5, 2019, s. 311-351.

Kętrzyński Wojciech, O paryskim rękopiśmie Pułkawy (Przedruk z „Roczników Towarzystwa Przyjaciół Nauk Poznańskiego", t. 5), TPN, Poznań 1869.

Korzon Krystyna, Wojciech Kętrzyński 1838-1918. Zarys biograficzny, Ossolineum, Wrocław 1993.

Kronika Uniwersytetu Jagiellońskiego od r. 1864 do r. 1887 i obraz jego stanu dzisiejszego wraz z rzeczą o rektorach od czasów najdawniejszych, wydanie Senatu Akademickiego na pamiątkę otwarcia Collegium Novum, Kraków w drukarni Uniwersytetu Jagiellońskiego, Kraków 1887.

[Liske Ksawery], Übersicht der polnischen historischen Literatur der letzten Jahre, „Historische Zeitschrift” 18, 1867, s. 359-410, https://www.digizeitschriften. de/download/PPN331411849_1867_0018/PPN331411849_1867_0018_log16.pdf (dostęp: 3 I 2020). 
Maternicki Jerzy, Epoka Ksawerego Liskego (1871/72-1891/92). Dydaktyka i badania, w: idem, Złote lata historiografii polskiej we Lwowie, Wydawnictwo Uniwersytetu Rzeszowskiego, Rzeszów 2015, s. 91-124.

Maternicki Jerzy, Historia $i$ życie narodu. Poglądy i postawy historyków polskich XIX i XX w., Wydawnictwo Uniwersytetu Rzeszowskiego, Rzeszów 2009.

Pamiątka drukarni J.I. Kraszewskiego w Dreźnie 1868-1871, Drukarnia J.I. Kraszewskiego, Drezno 1871.

Perkowska Urszula, Józef Szujski - pierwszy sekretarz generalny Akademii Umiejętności w Krakowie, w: Amico, socio et viro docto. Księga ku czci profesora Andrzeja Kazimierza Banacha, red. Tomasz Pudłocki, Krzyszof Stopka, Historia Iagellonica, Kraków 2015, s. 199-218.

Pisulińska Joanna, Polska XVI wieku w pracach historycznych Wincentego Zakrzewskiego, w: Wspólne dziedzictwo. Rzeczpospolita Obojga Narodów w polskiej, litewskiej i ukraińskiej historiografii XIX i XXI wieku, red. Mariola Hoszowska, Joanna Pisulińska, Paweł Sierżęga, Leonid Zaszkilniak, Wydawnictwo Uniwersytetu Rzeszowskiego, Rzeszów 2019, s. 130-140.

Skrobacki Andrzej, Dlaczego Wojciech Kętrzyński nie otrzymał katedry na Uniwersytecie Krakowskim w 1869 roku?, „Komunikaty Warmińsko-Mazurskie” 1973, nr 3, s. 209-212.

Stinia Maria, Biblioteka Seminarium Historycznego Uniwersytetu Jagiellońskiego w latach 1873-1918, w: Virtuti et ingenio. Księga pamiątkowa dedykowana profesorowi Julianowi Dybcowi, red. Andrzej K. Banach, Historia Iagellonica, Kraków 2013, s. 465-476.

Stinia Maria, Katedra historii polskiej na Uniwersytecie Jagiellońskim, w: Katedra historii polskiej na Uniwersytecie Jagiellońskim - odniesienia, interpretacje, pamięć, red. Krzysztof K. Daszyk, Tomasz Kargol, Historia Iagellonica, Kraków 2019, s. 9-35.

Stinia Maria, Uniwersytet Jagielloński w latach 1871-1914. Modernizacja procesu nauczania, Historia Iagellonica, Kraków 2014.

Szujski Józef, Przegląd historycznej literatury polskiej lat ostatnich, „Przegląd Polski” 2, 1868, 3, 9, s. 508 [oryg. Übersicht der polnischen historischen Literatur der letzten Jahre, „Historische Zeitschrift” 1867].

Szujski Józef, Studia z dziejów wieku XVI, napisał Xawery Liske, dr fil.[ozofii], Poznań, nakładem księgarni Żupańskiego, „Przegląd Polski” 2, 1867, 1, 3, s. 465-467.

Walewski Antoni, Geschichte der hl. Ligue und Leopolds I. vom Umschwung im Gleichgewichtssystem des Westens durch den schwedisch - polnisch - österreichischen Krieg, bis zur Verwicklung der orientalischen Frage durch August II 1657-1700, t. 1, cz. 1, In der K.K. Universitäts-Buchdruckerei, Kraków 1857.

Walewski Antoni, Historia wyzwolenia Polski za panowania Jana Kazimierza 16551660, Drukarnia Uniwersytetu Jagiellońskiego, t. 1, Kraków 1866; t. 2, Kraków 1868.

Zakrzewski Wincenty, Codex diplomaticus Tinecensis. Kodeks dyplomatyczny tyniecki, wydany staraniem i nakładem Zakładu Narodowego imienia Ossolińskich. Cz. I-sza, XIII-ty i XIV-ty wiek, Lwów, w drukarni Zakładu Narodowego im. Ossolińskich 1871. 4-o, str. VII, 198, w: „Niwa. Dwutygodnik Naukowy, Literacki i Artystyczny” 1, 1872, 1, nr 6, s. 137-141; nr 7, s. 172-174; nr 8, s. 195-197. 
Zakrzewski Wincenty, Powstanie i wzrost reformacji w Polsce 1520-1572, Fr. Wagner, Lipsk 1870.

Zakrzewski Wincenty, Xawery Liske, 1838-1891. Wspomnienie pośmiertne, nakł. autora, Kraków 1891.

Zamorski Krzysztof, Historyzm i narodziny krakowskiej szkoły historycznej. Józef Szujski, w: Józef Szujski 1835-1883. Materiały z posiedzenia naukowego w dniu 25 listopada 2013 roku, red. Wanda Lohman, PAU, Kraków 2015 (W służbie nauki, nr 26), s. 51-59.

Biogram: Agnieszka Kawalec, dr, adiunkt w Instytucie Historii Uniwersytetu Rzeszowskiego, zajmuje się dziejami Galicji, historią intelektualną XIX w., biografistyką; kontakt: kawalecagnieszka@gmail.com.

Author: Agnieszka Kawalec, PhD, assistant professor at the Institute of History of the University of Rzeszów; her research interests cover: the history of Galicia, intellectual history of the nineteenth century, biographical studies. Contact: kawalecagnieszka@gmail.com. 